Article

\title{
The Social and Vocational Integration of Former Users of the Child Protection System in Romania: A Qualitative Study
}

\author{
Dănuț Bălăuță ${ }^{1} \mathbb{D}$, Alexandru Neagoe ${ }^{1, *}$, Marius Vasiluță Ștefănescu ${ }^{2}$ and \\ Ovidiu Florin Toderici ${ }^{3}$ \\ 1 The Department of Social Work, The West University of Timișoara, 300223 Timișoara, Romania; \\ danut.balauta@e-uvt.ro \\ 2 The Department of Sociology, The West University of Timișoara, 300223 Timișoara, Romania; \\ marius.vasiluta@e-uvt.ro \\ 3 The Faculty of Educational Science, Psychology and Social Work, Aurel Vlaicu University, \\ 310130 Arad, Romania; ovidiu.toderici@uav.ro \\ * Correspondence: alexandru.neagoe@e-uvt.ro
}

Received: 9 May 2019; Accepted: 14 June 2019; Published: 15 June 2019

check for updates

\begin{abstract}
The social and vocational integration of vulnerable groups is an important aspect of social sustainability. Former users of the residential child protection system represent such a group. The purpose of our research was to investigate the social and vocational integration of individuals raised in the child protection system in Romania. Their experiences during and after their time in residential care are analyzed. The research sample was composed of 23 interviewees (18 male and 5 female) with an average age of thirty-five at the time of the interview $(S D=7.49)$. Our research method was a qualitative one, based on a semi-structured interview. The results paint a generally bleak image of life in such institutions, both before the fall of communism in Romania in December 1989 and subsequently. In addition, the respondents' transition from institutional life to independent living was full of challenges. Nevertheless, most of the respondents have demonstrated a remarkable level of resilience, based on factors such as education, self-esteem, work, a life partner and the ability to acquire new skills. As a general conclusion, our study has shown that a sustainable social development plan should include social policies which strive for the de-institutionalization of the child protection system by preventing the separation of children from their biological families or, where necessary, by finding family-type solutions for children in difficulty. If institutional childcare is to continue, it must be accompanied by consistent efforts to prepare these children for their transition to independent living.
\end{abstract}

Keywords: child protection system; youth; institutionalization; institutional care; social and vocational integration; Romania

\section{Introduction}

\subsection{Children's Welfare and Sustainable Development}

In view of recent academic studies which highlight the social dimension of sustainable development [1,2], it is apparent that the sustainable development of any society must include appropriate strategies for the social and vocational integration of such vulnerable groups as formerly institutionalized youth [3].

It is particularly significant to note that among the Sustainable Development Goals (SDGs) which were set by the United Nations General Assembly in 2015 for the year 2030, among the 17 goals, one 
specifically sets out to "promote peaceful and inclusive societies for sustainable development, provide access to justice for all and build effective, accountable and inclusive institutions at all levels" [4]. Moreover, as indicated by SOS Children's Villages, five of the 17 Sustainable Development Goals of this programmatic document may be seen as directly affecting children's welfare and opportunities for the future [5]:

- Goal 1: End Child Poverty

- Goal 4: Ensure Quality Education for All

- Goal 8: Equal Job Opportunities for All

- Goal 10: Reduce Inequality within and among Countries

- Goal 16: Promote Peaceful and Inclusive Societies

Similarly, the Child Rights International Network (CRIN) rightly points out that "children are affected by all of the sustainable development goals, whether poverty, hunger, inequality or climate" [6]. Clearly, such observations are particularly relevant to those who, for various reasons, did not have the privilege of experiencing childhood in a family environment and who, instead, had to be raised in social care institutions. For this category of population, not only their childhood, but also their transition to adult life, is subject to major challenges. Sustainable social development must, therefore, include adequate solutions and resources for these special challenges which such social groups need to face.

For young people in general, the transition from childhood to adulthood is a process which involves not only numerous biological and social changes, but also a wide range of personal challenges. For those who have been raised in the child protection system, however, this transition is often not accompanied by the positive resources which are typically available to children and teenagers who have been brought up in a family environment (such as financial resources for further study, personal support to deal with crises and changes, etc.) [7]. Their abrupt exit from the child protection system, at a time when other young people are still enjoying the valuable support of their extended families, makes their transition to independent living a difficult road to travel.

\subsection{Children in the Romanian Residential Care System - and Beyond}

It is widely accepted that the role of residential care is to provide a safe environment for children or youth who, for a variety of reasons, are unable to live with their biological family or in an alternative family environment, such as foster care [8]. In the case of Romania, numerous young people raised in such an environment have lived for many years with very limited opportunities for personal and vocational development. They have also very often been the victims of abuse, discrimination, and neglect.

According to the National Agency for the Protection of Children's Rights and Adoption (ANPDCA) in Romania, the number of institutionalized children, at the end of 2008 was 24,427, at the end of 2012 was 22,798, and at the end of 2015 was 20,291 [9]. The most recent statistics, published by the same entity, show the situation on the 31 December, 2017. At this date, a total of 55,302 children were living in the child protection system and out of this number, 18,197 were placed in residential care $(14,492$ in public institutions and 3705 in private institutions).

According to age groups of the children in residential care, the situation on the 31 December, 2017 is as indicated in Table 1.

As indicated by these statistics, a very high percentage of the children in difficulty, in Romania, continue to live in residential institutions. This has occurred, despite social policies which, in recent years, have aimed to decrease the number of children living in the residential care system and the efforts which have been made to identify family-type solutions for the children in difficulty [11]. Moreover, despite the numerous and severe challenges which institutionalized children have to face, society at large often expects them to be fully emancipated and socially adjusted as soon as they leave the special care system [12]. 
Table 1. Number of children per age group, on the 31 December, 2017.

\begin{tabular}{ccccccccc}
\hline $\begin{array}{c}\text { Residential } \\
\text { Services }\end{array}$ & $\begin{array}{c}\text { Below } \\
\text { 1 Year }\end{array}$ & $\begin{array}{c}\mathbf{1 - 2} \\
\text { Years }\end{array}$ & $\begin{array}{c}\text { Years } \\
\text { Years }\end{array}$ & $\begin{array}{c}\mathbf{7 - 9} \\
\text { Years }\end{array}$ & $\begin{array}{c}\mathbf{1 0 - 1 3} \\
\text { Years }\end{array}$ & $\begin{array}{c}\mathbf{1 4 - 1 7} \\
\text { Years }\end{array}$ & $\begin{array}{c}\text { over } \\
\text { 18 Years }\end{array}$ & Total \\
\hline public & 186 & 234 & 1033 & 1630 & 3628 & 5848 & 1933 & 14,492 \\
private & 8 & 15 & 270 & 622 & 1149 & 1258 & 383 & 3705 \\
total & 194 & 249 & 1303 & 2252 & 4777 & 7106 & 2316 & 18,197 \\
percentage & $1.1 \%$ & $1.4 \%$ & $7.2 \%$ & $12.4 \%$ & $26.3 \%$ & $39.1 \%$ & $12.7 \%$ & $100 \%$ \\
\hline
\end{tabular}

Source: The [Romanian] National Authority for the Protection of Children's Rights and Adoption (ANPDCA) (Authors' translation.) [10].

The results of a study of 206 post-institutionalized youth in Romania [13] showed that $86 \%$ of participants had stable housing arrangements (50\% of them living on their own and the other $50 \%$ in shared accommodation), while the remaining $14 \%$ reported no stable housing arrangements, living instead on the streets, in parks, in municipal heating tunnels, or in the stairwells of apartment blocks. The investigated population was divided into four groups, depending on their housing situation: 29 were homeless, 58 lived by themselves, 48 lived in community flats belonging to Christian foundations, 68 lived in social housing provided by the city administration, while 3 respondents declined to give any information on the subject.

\subsection{International Research on Post-Institutionalised Youth}

Building on previous studies [14-16], Mike Stein divides former users of the child protection system into three categories [17]: The moving on group (those who have moved on successfully), the survivors; and the victims. Those who have moved on are most likely to be young people who have had the advantages of stability, continuity, and a secure attachment. They have typically had good school results, have been gradually prepared for independent living, and have moved out of the special care system at a later stage. For this category of people, a greater degree of control over their own lives has come as a positive and welcome development.

The survivors are those who have experienced more instability, have left the child protection system at an earlier age, and have had little training for independent living. They are likely to encounter significant difficulties after leaving the social care system, including lack of housing, an inability to find permanent work, insufficient income, and problems in their personal lives. The personal and vocational support which they receive (or do not receive) after leaving the child protection system will make the difference between successful or unsuccessful social integration. Also, peer mentoring from older youth who have come from the same context can represent a valuable resource in their journey to independence [17].

The victims are those young people who have had harmful experiences in their families and have been subjected to numerous institutional re-locations in the course of their life, thus disturbing previously-established relationships. They typically have to deal with a wide range of difficulties in terms of emotions, education, behavior challenges. Once they leave the system, they are likely to encounter unemployment, homelessness, isolation, loneliness, and mental health issues $[17,18]$.

Generally speaking, the social and vocational integration of these young people depends to a significant extent on the quality of the care provided in the institution and on the level of support they receive on leaving the institutional system [17]. A particular problem is that their employment opportunities are relatively limited due to a low level of vocational qualifications. Moreover, their social and vocational integration is made difficult by a number of other factors, such as poor living conditions; low or unstable socio-economic status; discrimination based on race, ethnicity, religion, or gender; limited access to health services; high risk of substance abuse.

Curry and Abrams $[19,20]$ have pointed out that for these young people financial independence is often impossible to achieve. Longitudinal studies have indicated that they have lower incomes and a higher rate of unemployment as compared to young people of similar age who have been raised in 
families. For those who do find employment, their income is often insufficient to keep them above the poverty line [19-21].

Trout, Hagaman, Casey, Reid and Epstein [22] carried out an analysis of previous studies related to the academic status of children and youth in out-of-home care. The twenty-eight studies taken into consideration led them to the conclusion that a third of these children and youth had poor school results. In addition, many had changed schools several times, had repeated a school year, had a high rate of absenteeism or had even been excluded from or dropped out of school. Similarly, Mayock, Corr and O'Sullivan [23] reported that young people who had experienced instability in their personal lives learnt not to expect long-term friendships, in order to avoid the possible disappointment of a relationship break-up. Mayock, Corr and O'Sullivan [23] found that the rate of illegal drug use among youth who lacked stable housing arrangements was higher than among other youth of a similar age. When drug use had begun during institutional care, the behavior was likely to continue after the person left the institution and to lead to other behavioral problems (such as criminal behavior). For homeless youth, drug use is often their first priority in life.

Against the backdrop of such international research, Romania has the potential to provide a particularly significant case study on the subject of post-institutionalized youth. The country's history, especially over the last thirty years, is particularly significant in this respect. The collapse of the communist system in December 1989, with the infamous orphanages which became visible to the world in the subsequent months and years; the new opportunities and challenges which were brought about by the joining of the European Union in 2007; the ongoing efforts to reform the social care system; the striving for a sustainable development [24] despite a more fragile economy than in most other EU countries, are all elements which underline the special significance of the present study on Romania.

Looking beyond strictly academic interests, it is hoped that through our research on the former users of the child protection system in Romania, this study may be able to contribute to the improvement of the services which are made available to this social category (in Romania or elsewhere) as they seek to adjust to independent living. A better understanding of their personal experiences and of the factors which help them during this transitional period in their lives is likely to facilitate the development of specific social programs which could assist other young people in similar life situations.

\section{Method}

The research method for our study has been interviewing and the research instrument which has been used is this respect was the semi-structured interview. The authors regarded this method as appropriate, given the exploratory nature of the approach in this study. A small amount of research is available to date dealing with the subject matter-the social and vocational integration of young people who were institutionalized in the child protection system in Romania before and after the fall of the communist system in the country. Consequently, the method, the selection technique and the research instrument, all belong to a qualitative approach, the content of the interview requiring an in-depth exploratory approach of the personal experiences of the individuals. As a result, the authors cannot, stricto sensu, speak of sampling or of a representative sample (which are methodologically specific to quantitative research) when selecting the subjects. The choice was, instead, of a rational sample which was selected with the help of the snowball technique. Our intention has not been to investigate a large number of cases, through a comparative style of quantitative research, but to reveal in-depth experiences of our interviewees. A further, quantitative research would, undoubtedly, constitute a useful but separate addition to our study.

The main goal of our research has been to investigate the social and vocational integration of individuals who have graduated from the child protection system in Romania (i.e., exiting the residential child protection system, usually between the ages of 18 and 26). More specifically, the authors have sought, not only to analyze their individual experiences, but also to identify the common features of their experiences during and after their time in residential care. Thus, our study has been guided by four specific goals: 
1. Documenting the difficulties which have been faced by people who have left the residential child protection system in Romania, as they have sought to move towards an independent life and social and vocational integration;

2. Identifying the services and opportunities which were available for individuals who grew up in the residential child protection system in Romania - the ones designed to help with their transition towards independent living;

3. Exploring the factors that made the difference between those who were more successful and those who were less successful in their social and vocational integration?

4. Delineating the common features and characteristics of respondents who, in terms of Stein's classification [17], could be placed, respectively, in the categories of moving on, survivors, and victims.

In our qualitative study, the role of dependent variables is fulfilled by: (1) The difficulties which the service users have encountered in their journey to independent living; (2) the services and opportunities which were available to them in this process, while the role of the independent variable is accomplished by the success of their social and vocational integration (including the correlation of this success to Stein's classification).

Due to the difficulty of quantifying the number of individuals who have graduated from the residential child protection system in Romania to date, our sample is non-probabilistic. Further, given the characteristics of the respondents, the study has made use of guided sampling.

The research sample consisted of 23 respondents-18 male and 5 female. Participation in the research was voluntary for all respondents and was based on informed consent, which included a guarantee of the confidentiality of the data. The respondents came from five counties in the west and south of Romania: Arad, Gorj, Mehedinți, Timiș, and Olt. The method of snowball sampling was used, in order to increase, as much as possible, the number of participants. Thus, the initial respondents' personal networks played an important role in our finding of new participants for the study. Additionally, a written request was made for the support of the General Directorate of the Social Work and Child Protection System (DGASPC) in each of the five counties. Despite of the kind cooperation of the DGASPC's, the identification of a larger number of respondents was severely hampered by several factors, including: the legal restrictions for the child protection institutions in offering contact information for the former service users; the lack of ongoing contact between institutions and former beneficiaries; the reluctance of many potential respondents to provide information about their traumatic past experiences (especially in interview format, rather than survey), etc.

Our research method is a qualitative one, based on a semi-structured interview. The procedure followed in the processing and validation of the data was thematic analysis. The criteria of this procedure were therefore observed, in order to eliminate subjective descriptions of the reality and uncover the respondents' relevant experiences during and after their residential life. The interview guidelines were directed towards four main thematic areas of investigation:

- The circumstances which led to their being placed in residential care;

- The actual experience of residential care;

- The transition towards an independent life, after the institutional experience;

- The current situation.

The interview findings were put together as individual life stories and this led to a number of specific themes emerging both from the similarities and from the differences between the individual stories. Particular fragments from the interviews have been selected, in order to illustrate the main themes of the transcripts. All quotations from the interview transcripts closely follow the participants' own words and have simply been translated from Romanian into English.

For reasons of confidentiality, each participant was given a pseudonym, which was kept the same throughout the study. The ages of respondents have not been changed. However, potentially 
identifiable data (such as place names, names of residential centers or staff) has been eliminated from the presentation of the results, for the same reasons of confidentiality. Once the issue of confidentiality had been clarified with the participants, they seemed to be comfortable to speak freely. For many of them, an additional motivating factor in their decision to participate in the study was their hope that their experience might be of help to other users of the child protection services.

Given the descriptive and qualitative nature of the investigation of individuals who have been raised in the residential child protection system in Romania, our approach is aimed at generating hypotheses rather than at testing existing theories. Such testing is far more suitably pursued via quantitative research [25].

\section{Results}

The group of participants in our study consisted of twenty-three individuals who had experienced life in a residential child care center. From this, eighteen were male and five female, with an average age of thirty-five at the time of the interview $(S D=7.49)$. Figure 1 shows the level of education attained by the participants, while Figure 2 indicates their marital status.

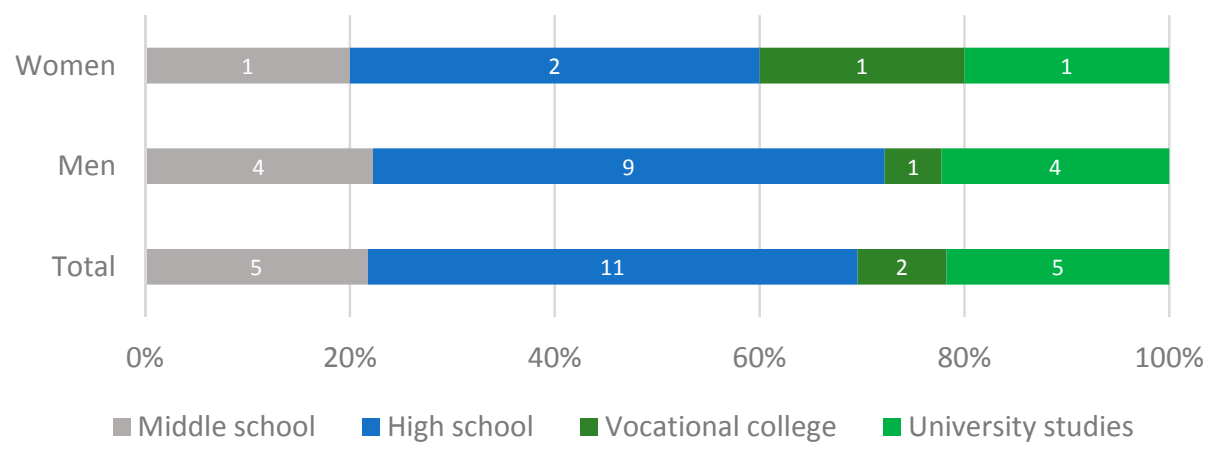

Figure 1. Level of education attained.

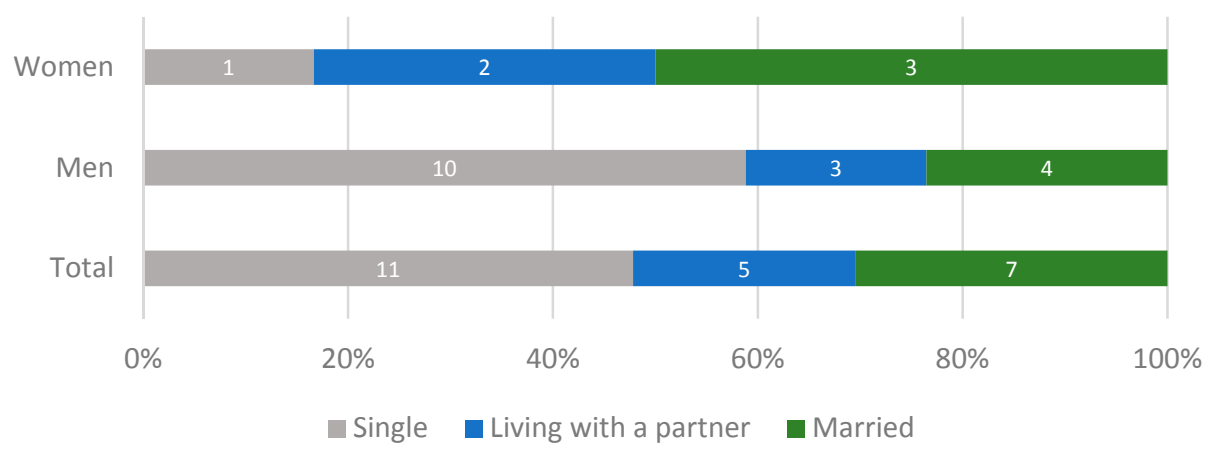

Figure 2. Marital status.

Socio-demographic data about the participants is shown in the Table 2 below: 
Table 2. Participants' socio-demographic data.

\begin{tabular}{cccccc}
\hline Pseudonym & Age & Marital Status & Children & Education & $\begin{array}{c}\text { Current Job and Employment } \\
\text { Sector (Public/Private) }\end{array}$ \\
\hline Paul & 32 & Single & No & University degree & Salesperson - private \\
Virgil & 40 & Single & No & University degree & Social worker - public \\
David & 46 & Single & No & High school & Security guard - public \\
Cristian & 49 & Married & Yes & High school & Cook - public \\
Daniel & 33 & Single & No & University degree & Assistant cook - private \\
Robert & 42 & Single & No & Middle school & Construction worker - private \\
Adam & 55 & Married & No & Vocational college & Police officer - public \\
Elena & 30 & Living with a partner & Yes & Vocational college & Nurse - public \\
Maria & 30 & Married & No & Middle school & Housewife \\
Levi & 30 & Living with a partner & No & High school & Hospital porter - public \\
Constantin & 31 & Living with a partner & No & High school & Production worker - private \\
Laura & 35 & Married & No & High school & Housewife \\
Paula & 38 & Single & No & High school & Nurse - public \\
Ana & 45 & Married & Yes & University degree & Social worker - public \\
Alex & 31 & Married & No & High school & Security guard - private \\
Darius & 28 & Single & No & Middle school & Unemployed \\
Bogdan & 28 & Single & No & High school & Production worker - private \\
David & 29 & Living with a partner & No & High school & Production worker - private \\
George & 28 & Single & No & High school & Unemployed \\
Denis & 28 & Single & No & Middle school & Unemployed \\
Samuel & 34 & Married & No & University degree & Doctor - public \\
Marius & 29 & Single & No & High school & Salesperson - private \\
Florin & 34 & Divorced & No & Middle school & Unskilled worker \\
\hline
\end{tabular}

\subsection{Circumstances Leading to Residential Care}

\subsubsection{Abandonment}

Eighteen of the twenty-three respondents stated that they had been abandoned shortly after birth, while two had been put into institutional care a little later, around the age of two or three. Generally speaking, the respondents had very little official information regarding the reasons for their having been abandoned but suspected that the decision had been taken due to an unwanted pregnancy or to poverty. Such data was not recorded in their personal files and any information they did receive came from discussions with residential center staff.

“[ ... ] I am about to turn thirty-two. I was in a children's home. I did not have parents. I did not have luck." (Paul)

"I don't know anything about my mother, father, brothers or sisters. Nobody has ever come to look for me. I have not seen them." (Florin)

"I believe my parents were poor and had other children. Otherwise they would not have put me in a children's home." (Maria)

"My mother did not have any options. She gave birth to me when she was very young. She was sixteen." (Ana)

"She probably got pregnant unintentionally and then just wanted to get rid of me. I don't care. I have never looked for her and she has never come to me." (Alex)

The following statements confirm previous research related to abandonment [11,26,27], which identifies poverty as the main reason for the abandonment of children in Romania, both during the communist period and after the changes of 1989.

"I was abandoned because they did not have the resources to raise me." (Samuel)

"I was abandoned around the age of three, when my mother was unable to care for me any longer, because my father had died and, being on her own, she could not cope any longer, so she took me to the children's home." (Constantin) 


\subsubsection{Neglect}

Only one respondent, who had been institutionalized in 1978, identified a situation of neglect (following a tragic accident) as the reason for his being taken into residential care:

"A more difficult case. One of my sisters died and this led to all of us (myself and my two elder brothers) being taken away from home. My father unintentionally killed my sister. He had a large piece of wood on his back and when he threw it down he did not know that she was behind him. He injured her head and she died. He then had a nervous breakdown, followed by violence against my mother and brothers. They arrested him and took us all away. My mother was pregnant with me. They took me immediately after I was born. They did not take their [my parents'] parental rights. If there was a fatal accident in the family, the children were automatically taken away from that environment." (Virgil)

\subsubsection{Medical Recommendation}

During the communist period in Romania, it was common to place a child in residential care on the recommendation of a doctor. Children who were abandoned at birth due to socio-economic reasons were typically taken for medical care. As a result, their problems, which were initially attributed to their social conditions, transformed the children into medical cases [28]. In the case of David, who was put into residential care during kindergarten as a result of a medical problem which was apparently not very serious, the authorities did not allow him and his brother (who had the same medical condition) to return to their family. Also, although there were triplets, only two of the three children were put into residential care. He does not know the reason for this:

"I and my twin brother went into hospital covered with blisters and they just kept us. I remember when they took us away from the hospital and put us in the center. I was around three." (David).

Similarly, Levi states that he was abandoned in a pediatric ward on the recommendation of a pediatrician who considered that returning him to his family would be too risky due to their poverty.

\subsection{The Experience of Residential Care}

\subsubsection{Multiple Placements}

The time spent in residential care is described by all respondents as a time of great instability. Except for one person (Cristian) who lived in only two institutions, all other participants lived in at least three different residential institutions during the time they spent in the Romanian child protection system. The participants described moving from one institution to another as an episode of instability and of readjustment to a new environment, with new staff and new fellow-residents. There was contact with a large number of caregivers, followed by the breaking of ties with them, which meant that it was impossible to develop lasting attachments [29]. Samuel's statements are a clear illustration of this:

"I was very sorry to leave the $X$ center, when they decided to move me somewhere else ... There was a lady carer of whom I was very fond. She still came to see me for two or three years, but then she left the country and I have not talked to her since. I don't know anything about her any more. I hope she is well ..." (Samuel)

The transfer to new institutions where older children were present also meant a high probability of conflicts and physical abuse:

"When we went to the $\mathrm{X}$ center, we moved into the girls' territory. They were older and kept trying to beat us up, in order to establish their territory". (Virgil, a male participant, speaking about his transition to a mixed center)

\subsubsection{Abuse}

The physical, emotional and sexual abuse that took place in Romanian children's homes during the communist regime has been well documented in the specialist literature. The research has indicated that the likelihood of a child being harshly punished by staff, and the frequency of such punishment, 
were influenced both by individual factors and by institutional ones. Thus, as far as the child's individual variables were concerned, it was found that a lengthier stay in the institution was associated with a higher probability of physical punishment by staff; that the probability was higher for boys than for girls; and that the absence of siblings in the same institution was also associated with more severe and frequent punishments. By contrast, when institutional variables were analyzed, they indicated that children in traditional institutions were more likely to experience physical abuse than those living in family-type settings [30]:

"They told us to fight among ourselves: the care staff [names were given]. Even rapes used to take place. I said that I did not want to fight, but they insisted, because they were laying bets on who would win. It did not matter that you ended up smashing your head or that you got injured when you jumped off the wardrobe. Unfortunately, I was very badly injured when I jumped off the wardrobe. The General Directorate for Social Work and Child Protection (DGASPC) found out about this. I was taken to an emergency unit in the hospital because I had a serious head injury. This is why I ran away from the center, in around 2003 or 2004 ..." (Paul)

Physical abuse (beatings) was experienced by all respondents, to different degrees, and was inflicted both by staff and by older residents. Female respondents reported fewer experiences of physical abuse from staff, but altercations with other female residents were often accompanied by physical aggression.

The sexual abuse that took place in these residential centers has been documented in numerous studies [30-32]. The participants in our study confirmed the findings of such studies: Seven of them (three female and four male) had been victims of sexual abuse; six other respondents had witnessed sexual abuse in the institutions but reported this without specifying whether or not they had been victims. None of the respondents stated that they had been an aggressor. Below is part of the testimony of one respondent regarding the repeated sexual abuse he was subjected to at approximately the age of nine:

"I had a nickname... There was a female teacher who abused me ... sexually ... to have oral sex $\ldots$ and from then on I was given her name as a nickname [the exact name is given]. She was very fond of me from the moment I had this relationship with her ... I am finding it very hard to say this ... In a way, from the moment I had sex with her there was a very special relationship. She used to take me to her relatives' home and she used to defend me. She was my teacher from the second to the fourth grade in school. I was very fond of her and she was fond of me. It was found out that I had slept with her and they wanted to fire her. She insisted that it was not true and I said the same, but eventually she ended up being prosecuted and they kicked her out". (Paul)

\subsubsection{Educational Challenges}

Among the factors which have been identified by previous research as making a significant contribution to the educational challenges faced by children in residential care are the instability of the child protection system; the children's previous experiences of abuse and neglect; inadequate care in the institution; low expectations from carers and educators; and untreated mental health problems, leading to social isolation and exclusion from school [31-34]. The results of our study confirm these previous findings:

"In school, we were trying to do all kinds of things in order to demonstrate to our colleagues and teachers that we were not stupid or handicapped just because we came from a children's home. I was part of the literature elite group ... At our center it was about the same. They didn't use to ask about our homework because they were not expecting that we would ever achieve anything. We were just told: "You will never achieve anything" or "You will end up on the street". (Elena)

"In school, I was top of the class. My school results were good. I was successful in my studies. We had a large library in our center. When there were a lot of fights/beatings, I used to take refuge in the library, and so I ended up acquiring new information. [ . . . ] They would tell us "You will end up 
in prison" and so it was, or "You will do well" and they were right. Because they were our mentors, they could see our abilities and the steps we were making". (Virgil)

\subsubsection{Little Contact with Family Members}

Although the communist policy did not make it a priority to encourage contact between children and their families, and children did not receive much information about their family situation, it is nevertheless the case that one of our respondents spoke of the staff of the center in which he had spent his school years as making an effort to support and enhance the children's contact with their nuclear or extended families:

"I was visited by my mother, father, and grandparents. I had two older brothers who were with me. I communicated with my family and with my grandparents from the time I was little. During summer holidays I used to run away to my grandparents [ ... ] They [the staff] encouraged contact with our families, but very careful checks were made to see whether our parents were OK. The visits took place only here [at the center], depending on how our parents were. For instance, if my father represented a danger, they would call the militia". (Virgil)

Another respondent spoke of the difficulty of finding our information about one's family during the communist regime, as compared to the current situation: "Yes, data was secret. Sometimes we used to ask the carers and they would tell us certain things about our parents. Nowadays, the children just go and look at their personal file, if they wish". (David)

This study can discuss family contact during and after residential care in the case of seven of the respondents. Sixteen respondents had no contact with their biological family, as a result of their having been abandoned in a maternity ward. For eleven of them, although they eventually had the chance to meet their parents (a few times), relationships with these parents remained tense. Their answers made clear their feelings of revulsion towards the parents and their disappointment when affection was not shown:

"Why did they leave me in the children's home? They should come to me and ask for forgiveness. I am not guilty of anything". (Alex)

"When I first met my mother and gave her a hug, I could feel the rejection". (Adam)

"The social workers contacted my mother but she did not want to come. I would like to meet her, to talk, even if she is not interested in me". (Laura)

\subsubsection{Struggling to Acquire Life Skills}

In contemporary Romania, both governmental and non-governmental children's services organize and implement activities which are intended to prepare children for an independent life in the future. During the communist regime, such organized programs or services were simply non-existent:

“They kept telling us 'Start learning something, because you will be in trouble. If you don't work, no one will give you anything'". (David)

"Nobody taught me anything, but I learnt to find my way around. I realized that if I learnt and if I was disciplined, I would manage by myself and this is exactly what has happened. I have never avoided work". (Adam)

It would seem that during communist times, the child protection service employees saw their role as basically to warn the children about the problems they could expect in the future if they did not learn how important it was to find your own way in life.

For respondents who were born after the communist period or who have lived most of their lives after it ended, the experience was significantly different. They reported being involved in various activities which were designed to help them acquire new skills and to prepare them for independent living. They spoke about being involved in programs designed to teach skills for everyday life, for personal care, for financial management, and for appropriate behavior in society and at their place of work. 
"[ ... ] help in finding a job, training for social integration, preparation for being in society and for getting out of the system, not to complain, because we would have to manage life by ourselves. They would teach us how to write a CV [ ... ] During the last year of school, for the final four or five months, we took classes about how to move out of the system". (Paul)

"They taught us how to behave in society, to be careful, not to cause conflicts. They got us involved in cleaning, washing. They would ask us sometimes about our homework and they would get upset if we were fighting in school. We have learnt things [ ... ] They told us [girls] to be careful, because some boys would simply want to take advantage of us". (Maria)

"Money stuff, how to save, how to find a job, how to behave as employees ... " (George)

\subsubsection{Basic Living Conditions}

Regarding living conditions, respondents who were born and raised during the communist period do not seem to be as critical of the child protection system as those who experienced it shortly after the Romanian revolution of 1989 or even later. The references to residential life in communist times are unanimous in indicating that, despite the very simple conditions, basic material needs were generally met:

"I liked it in those days. There was a guaranteed food supply. Out in town, people were queuing up for food, gas bottles, bread. It was hard. In the institution we had chicken, pork, even salami and sausage. Ceausescu [the Romanian communist dictator] cared about the orphans". (Cristian)

"Children's homes had plenty of food, but the staff used to steal. We had two hundred pigs, we had rabbits and pigeons. Ceausescu was our father. In the autumn, a truck with potatoes would come-they would rot in the basement. Cabbage would come. Butter would come in $5 \mathrm{~kg}$ blocks, jam, cheese, salami [ ... ] They would bring meat, we had the pigs, but we would only get the bones and the fat, because the rest was stolen by the staff and by those from the [communist] party. They would take first. Those who say it was bad are lying. [ .. ] ] For me, it was good in the children's home, although there were ugly things, too. There was a lot of beating". (Virgil)

\subsubsection{Survival Strategies}

For some respondents, siblings in the same center represented a major element of support, not only emotionally, but also because younger siblings were protected by older siblings against abuse from other residents: "Without my brothers, I don't think I would have survived. It was a great help to have my brothers with me. They paved the path for me. They were older. I was also spared a lot of beating". (Virgil)

At the same time, Virgil also tells how important his personal ambition was for his resilience: "I had a lot of trust in myself. Ever since I was little, I always knew what I wanted. I knew I needed to have my own house, to be independent, to not depend on anybody. [... ] Even before the [Romanian] revolution I was OK. There were staff members who would beat me up and others who were fond of me."

Again, Virgil explains that another important survival mechanism inside the center was to belong to a gang, "otherwise they would lynch you", given the fact that there was no place where you could hide away from beatings.

Further, the ability to make yourself likeable and useful to the staff, by performing certain tasks, could confer significant advantages:

"Yes, there was a teacher who would see me as his child, because I knew how to make myself likeable. If you don't know how to make yourself likeable to society, it is not good." (Virgil)

"I liked it in the kitchen, which is why I have become a cook. I enjoyed being in the kitchen when I was little. I would wash dishes, I would peel potatoes, I would do what I was told". (Cristian)

"One of the teachers sometimes took me to her home. In general, I was well-behaved and I did not get into conflicts. Sometimes I helped with different tasks. Even at school, I did not create problems, 
although I was not a very good student. I could have done more, if the teachers had been different". (Maria)

David, currently employed in the child care system, reports that when he was a service user himself, he used to take care of younger children without necessarily being asked to do so. He shows some disappointment that the staff did not distinguish more between those who looked after younger children and those who did not get involved. However, the management of the center approached him and offered him a job.

\subsection{The Post-Residential Transition}

For seven of the respondents, the difficulties involved in the transition to independent life were mitigated by a solid education, employment, access to housing, and emotional support either from their family of origin or from other people.

Referring to his expectations of independent life, soon after leaving the system, David replied that "then it is the hardest, the hardest of all. It is very difficult for a child to leave the system". For him, the most important support on leaving the system was finding a job and his successful transition to an independent life was mediated primarily by putting work first. He has never been homeless but admits that he was afraid of this possibility when he first left the center.

For Cristian, leaving the system was marked by severe anxiety:

"I had a knot in my stomach at the thought of being on my own ... I finished school, I was told to look for work. I told them to look for it for me, thinking that if someone in the DGASPC made the request it would be different. It would mean I had a recommendation. My first job, for six or seven years, was as a cook, at a nursing home. From there I moved here."

Interviewer: "So, how was it trying to find a job?"

Cristian: "The headmistress sent us to various private companies where she had connections. There were classmates who went there and were not given their pay. I knew about this from my classmates and I did not accept [those jobs]. I said that I wanted a job in the public sector: "Since you have employed other people for money, why don't you employ us, too? We are also reliable and we will keep our job [ ... ] I told them that I would go anywhere, if I had a public sector job, but not a private sector one, where I would risk not getting paid".

Interviewer: "After moving out of the system, where did you live?"

Cristian: "I rented a place. I moved to different rented places. For a period of about seven or eight years I lived in a small flat that belonged to the child protection department, paying rent".

Adam married soon after leaving the system, his transition to independent living being thus facilitated by being able to live at his in-laws', but also by the social and emotional support which they and his wife provided. He also made good progress professionally, as a traffic police officer, displaying good discipline and professionalism.

Paul continued to live on a university campus, having enrolled as an undergraduate and then a postgraduate student.

Maria had great difficulties when she left the system at the age of eighteen because of her limited education (middle school). She tried to work as a carer at a residential center for the elderly, while living with a friend, but conflicts with colleagues led her to quit. Shortly after resigning, she met her present husband and moved into his home. She started to work as a house cleaner on an occasional basis.

Samuel started a medical residency program (as a urologist) and then met his present wife, with whom he moved into a rented place.

An overall observation regarding the transition from the child protection system to independent living would be that this was longer and more complicated for some respondents than for others. The negative aspects being frequent changes of jobs and accommodation, including even some cases of homelessness (being forced to sleep in parks or at a railway station). 


\subsection{The Current Situation}

Paul is currently registered on a master's program and lives on a student campus. He has a steady job which gives him a regular income, even if it is not very high. His right to accommodation on the student campus is dependent on good academic results or on providing proof of a difficult social situation.

David lives in a rented place but would like to be able to eventually have his own home. Virgil, thanks to the support of a French organization, has owned a flat ever since 1999, when he was a user of the social protection system. Adam lives with his wife in a house which was purchased after his in-laws were able to sell some land. Samuel also lives with his wife, in a two-room apartment which was bought with a mortgage.

At the time of the interviews, three respondents were homeless: George, Denis, and Darius. They occasionally live with friends, or sleep in parks, in a railway station, at the back of some shops, or near a heating system located between apartment blocks. All the other respondents live in relatively modest housing facilities that they either own or rent.

As for employment, the respondents' jobs are generally not very well paid and, for most of them, these jobs provide them with the means of independent but modest living. Most respondents avoided being very specific about their regular income or whether they had any other sources of income in addition to their jobs. Some also mentioned occasional problems with paying rent or even with buying food.

\section{Discussion}

Most of the respondents in our study have demonstrated a remarkable level of resilience, given the serious challenges which they had to face during their childhood and youth. The factors which have contributed to their resilience are in line with the findings of previous research $[17,35]$ and include education, self-esteem, work, a life partner, and the ability to acquire new skills and social support [36].

The data indicate a generally bleak image of life in institutions, even if not all participants report having been the victims of abuse from carers (some of them, in fact, viewing the residential staff as genuine helpers). Our analysis of responses reveals both similarities and differences. All participants had to face major challenges during their time in residential care, including exposure to acts of physical violence (at least from older residents). A positive influence on their development seems to have been contact with other family members, where this was possible. Education and a desire to work have also been important predictors of a better quality of life after they left the child protection system.

The transition towards independent living was not without its challenges either, but the majority of respondents appear to have succeeded in their social and vocational integration, even if their income has never been particularly significant.

More specifically, our study has been guided by four specific goals which were designed to lead to the identification and promotion of specific interventions and programs for this vulnerable social category.

\subsection{Difficulties during the Transition Phase}

Regarding the first goal, concerning the difficulties which respondents encountered during their transition from the child protection system towards independent living and social and vocational integration, the results of our study have highlighted largely the same issues as those identified by previous research: Lack of proper housing; the difficulty of finding jobs, or anything beyond poorly-paid ones; and inadequate preparation for independent living [14,19,20,37,38].

\subsection{Services and Opportunities}

The second goal referred to the respondents' access to services and opportunities which could help them in their transition towards independent living. Our study has shown that such resources 
were quite simply unavailable in any official or organized form for those who were institutionalized during the communist regime in Romania. The only way in which someone could develop life skills was through the limited range of experiences which institutional life was able to offer. However, these respondents, who had been institutionalized in the communist period, seem to have done relatively well after leaving their institution. Most were able to find a job soon after leaving the child protection system, without needing to change jobs very often, and without experiencing periods of homelessness. This relative success was explained by the respondents as being related to their efforts in terms of education, personal discipline, and the determination to overcome the disadvantages of their situation in society. By contrast, those who experienced residential care after the fall of communism benefited from a range of programs which were intended to help with their transition towards independent living. They also enjoyed the advantages of more freedom to participate in the life of society, of a better quality of life, of social policies designed to facilitate their social integration, and so forth. Nevertheless, these younger respondents are those who seemed more inclined to highlight the difficulties they had encountered and to blame the child protection system for their problems. According to their understanding, taking part in the programs which were meant to be of help after they left the institution did not seem to have a very significant impact in this respect. This rather surprising finding, resulting from our second research question, undoubtedly represents one of the possible directions for further research: Were these resources, of the younger respondents, simply inefficient? Was the communist social policy (e.g., jobs and housing for everyone) a legacy which benefited the older respondents in their post-institutional life more than the newer strategies which were available to the younger respondents? Were the younger respondents (who had been raised in a democratic society) more courageous in reflecting and speaking critically about their institutional and post-institutional experiences? Is there a combination of these (and other) factors which explain the findings? A quantitative study, on a larger number of respondents, might be particularly helpful in providing further clarifications in this area.

\subsection{Success Factors}

The third question concerned the factors which made the difference between those who were more successful and those who were less successful in their social and vocational integration. Personal resilience seemed to have played a particularly significant role in this regard, indicating that, despite negative experiences during and after residential care, a resilient person could achieve a good level of social integration. Other factors which appear to have been significant are the support of family members or personal friends and the availability of a job.

\subsection{Common Features and Characteristics}

Fourthly, adopting Stein's classification [17] of former users of the child protection system into three categories (moving on, survivors, and victims), the authors set out to explore what might be some of the common characteristics of the respondents belonging to each of these categories. Despite the already-observed lack of standard terminology for describing such vulnerable groups in Romania, given the relative novelty of the social work profession in this country [39], overall, the respondents seemed to fit well into these three categories. Those who moved on were clearly the six respondents who had a higher level of education, a settled job, secure housing, and a good network of social support. The survivors were those (fourteen) who have managed to keep their heads above water, achieving a reasonable level of independence, but without enjoying true satisfaction and stability in regard to key issues such as education, jobs, housing, and social network. The remaining three respondents, who are homeless and unemployed, would fall into the category of victims.

\section{Conclusions}

Romania has drawn a lot of international attention, after the fall of the communist regime, both through the large number of institutionalized children and through the deplorable conditions in children's homes. For many years, the attention of the decision-makers in the country focused on the 
improvement of the material situation of those living in placement centers, while the situation of those who were living in the system became a much lesser priority. Consequently, although Romania has made considerable progress in improving material conditions in residential systems, young adults are still largely unprepared for their transition to independent life.

Related to this situation, our study offers a contribution towards a better understanding of the social and vocational integration of former users of the residential child protection system in Romania. The significance of our study is highlighted by the very limited number of studies on this topic in the Romanian social context. As the subject has been addressed by previous research $[11,13,28,29]$ and others, the focus has been primarily on young people who are still in residential care and much less on the experience of former service users in their transition towards independent living. It is here that our study has sought to offer its contribution, although, considerable room for further research in this area is still available.

Our study has taken a qualitative approach and, as such, it has not intended to establish a representative research sample and to generalize the results for the whole population of de-institutionalized youth. Instead, our aim has been to describe and understand phenomena related to the social and vocational integration of individuals who have left the child protection system in Romania.

The results of this study are relevant for both academic and professional groups focusing on this vulnerable population category worldwide. The sustainable development of a society should include social policies which strive for the de-institutionalization of the child protection system by preventing the separation of children from their biological families, or, at least, by finding family-type solutions for children in difficulty. Nevertheless, millions of children in different parts of the world are still living in residential care, although a precise estimation of their exact number (or even of the number of institutions which house them) is impossible to realize [40]. Notwithstanding the significant efforts which many countries are making towards the development of family-based child protection systems, a significant number of children worldwide will inevitably continue to live in residential institutions. It is, therefore, crucial that their residential living conditions are constantly re-evaluated and improved and that better mechanisms are developed in order to facilitate their subsequent social and vocational integration. Based on the findings of our research, the following practical implications may be noted:

- The need for supplementing the existing (human and financial) resources, in order to improve the quality of services during the residential care and in the transition towards independent living;

- The introduction of a system of external audit aimed at the evaluation and improvement of the quality of services during residential care (especially those services which are meant to help the young people as they prepare to exit the child protection system);

- Developing a more efficient system of supervision of the staff working with children in residential care, in order to minimize the risks of abuse, negligence, and malpractice;

- The development of specific projects, activities, and resources which are meant to facilitate the acquisition of skills for independent living (including personal financial management);

- The need for programs of early career orientation, based on the children's personal interests and on the market demand;

- Promoting social policies which encourage potential employees to facilitate jobs for former service users of the child protection system.

The limitations of our study should also be recognized. Given the fact that in Romania, youth that left the child protection system often do not want to maintain contact with service providers, reaching them for participation in research is extremely difficult, as their former care givers have very little information about their current situation (or are hesitant to offer it, even if they have such information). Thus, this study is limited by the fact that there are many young people who have left residential care and whose experiences have been completely undocumented. Undoubtedly, their life stories could significantly modify the overall picture which our study has afforded, especially since some 
potential participants may have refused to talk about their experiences due to their traumatic nature. The 23 respondents in this study may seem a small number for generating conclusions, but managing to have in depth interviews with such a reluctant segment of population is, nevertheless, an important step in the ongoing efforts of documenting their situation. Despite the limitations of our study insofar as its scope and its applicability to other similar groups are concerned, the value of our analysis resides (among other aspects) in its potential as a pilot study, intended to lay the groundwork for future studies in this important but under-researched subject. It is also the understanding of the authors that these limitations do not undermine the premises and objectives which have been assumed.

Our research, through the qualitative approach it proposes, documents (albeit partially) the social and professional integration of former users of the child protection system in Romania through an in-depth exploratory approach. This approach may be a theoretical support in conceptual clarification and operationalization of variables whose normal distribution can be described through a future quantitative study.

Author Contributions: Conceptualization, D.B. and A.N.; methodology, D.B., A.N. and M.V.S.; validation, D.B. and A.N.; formal analysis, A.N. and O.F.T.; investigation, D.B.; resources, D.B., A.N., M.V.Ș. and O.F.T.; data curation, D.B. and A.N.; writing — original draft preparation, D.B.; writing—review and editing, A.N.; visualization, M.V.S.; supervision, A.N.; project administration, A.N.; funding acquisition, O.F.T.

Funding: This research received no external funding.

Acknowledgments: Special thanks to Stuart and Dorothy Elford, for their help with revising the translation from Romanian into English.

Conflicts of Interest: The authors declare no conflicts of interest.

\section{References}

1. Dempsey, N.; Bramley, G.; Power, S.; Brown, C. The social dimension of sustainable development: Defining urban social sustainability. J. Sustain. Dev. 2011, 19, 289-300. Available online: https://www.researchgate.net/publication/229889535_The_Social_Dimension_of_Sustainable_Developm ent_Defining_Urban_Social_Sustainability (accessed on 14 October 2017). [CrossRef]

2. Dujon, V.; King, M.C. (Eds.) Understanding the Social Dimension of Sustainability; Routledge: New York, NY, USA; London, UK, 2009.

3. Vasiluță Ștefănescu, M. Occupational integration of people with intellectual disabilities by developing protected units, case study “Pentru Voi" NGO, Timisoara. An Stiint. Univ. Ai I Cuza Iasi 2018, XI, Nr.1/2018. 104-123. Available online: https://anale.fssp.uaic.ro/index.php/asas/article/view/516/462 (accessed on 22 July 2018).

4. United Nations General Assembly. Transforming Our World: The 2030 Agenda for Sustainable Development. 2015. Available online: https://www.un.org/ga/search/view_doc.asp?symbol=A/RES/70/1\&Lang=E (accessed on 2 November 2018).

5. SOS Children's Villages. The Sustainable Development Goals for Children-And How SOS Children's Villages Works for Them. 6 August 2015. Available online: https://www.sos-childrensvillages.org/news/sos -sdgs-children-post-2015 (accessed on 28 April 2018).

6. Child Rights International Network (CRIN). Protection of the Rights of the Child and 2030 Agenda for Sustainable Development. Available online: https://www.ohchr.org/Documents/Issues/Children/2030/CRIN .pdf (accessed on 12 June 2018).

7. Abrams, L.S.; Curry, S.R.; Lalayants, M.; Montero, L. The Influence of policy context on transition age foster youths' views of self-sufficiency. J. Soc. Serv. Res. 2017, 43, 37-51. Available online: https:/www.researchgate.net/publication/308272870_The_Influence_of_Policy_Context_on_Transition_Age_ Foster_Youths\%27_Views_of_Self-Sufficiency (accessed on 20 October 2017). [CrossRef]

8. Lupșan, G. Instituții juridice de protecție a copilului. Adopția. [Juridical institutions for child protection. Adoption]. In Tratat de Asistență Social [Treatise on Social Work], 2nd ed.; Neamțu, G., Ed.; Polirom: Iași, Romania, 2011; pp. 789-899.

9. ANPDCA Statistica [Statistics]. Available online: http://www.copii.ro/statistica-pe-ani/ (accessed on 28 November 2018). 
10. Autoritatea Națională pentru Protecția Drepturilor Copilului și Adopție (ANPDCA) [The Romanian National Authority for the Protection of Children's Rights and Adoption]. Available online: http://www.copii.ro/anp dca-content/uploads/2017/07/sinteza-statistica-copii-31.12.2017.xls (accessed on 2 November 2018).

11. Stănculescu, M.S.; Grigoraș, V.; Teșliuc, E.; Pop, V.; (Coordonatori). România: Copiii din Sistemul de Protecție a Copilului; Editura Alpha MDN: București, România, 2016. Available online: http://www.unicef.ro/wp-conte nt/uploads/Copiii-din-sistemul-de-protectie-a-copilului_UNICEF_ANPDCA_BM_2016.pdf (accessed on 21 May 2017).

12. Fryzel, L.; Evans, J.L. Y.O.U.T.H. Training Project: Foster Youth as Teachers to Transform Social Work. In Childhood, Youth, and Social Work in Transformation: Implications for Policy and Practice; Nybell, M.L., Shook, J.J., Finn, J.L., Eds.; Columbia University Press: New York, NY, USA, 2009; pp. 418-428.

13. Onica-Chipea, L.; Bălțătescu, S.; Chipea, F.; Oprea, I. Studiu Privind Modul de Integrare în Societate a Tinerilor Care au Fost Socializați în Instituțiile de Protecția Copilului în Județul Bihor. A Study of How Young People Socialised in Child Protection Institutions in Bihor County Have Integrated into Society, Oradea, Romania. 2008. Available online: http://www.socioumane.ro/downloads/centre_de_cercetare/Studiu\%20privind\%20modul\%20d e\%20integrare\%20in\%20societate\%20a\%20tinerilor\%20care\%20au\%20fost\%20institutionalizati.pdf (accessed on 11 September 2017).

14. Biehal, N.; Clayden, J.; Stein, M.; Wade, J. Leaving care in England: A research perspective. Child Youth Serv. Rev. 1994, 16, 231-254. [CrossRef]

15. Pecora, P.J.; Williams, J.; Kessler, R.C.; Downs, A.C.; O’Brien, K.; Hiripi, E.; Morello, S. Assessing the Effects of Foster Care: Early Results from the Casey National Alumni Study. Casey, Research Report. 2004. Available online: https://www.casey.org/national-alumni-study/ (accessed on 18 November 2017).

16. Sinclair, I.; Gibbs, I.; Wilson, K. Foster Placements: Why They Succeed and Why They Fail (York Study 2); Jessica Kingsley: London, UK, 2004; pp. 55-69.

17. Stein, M. Research Review: Young people leaving care. Child Fam. Soc. Work 2006, 11, 273-279. Available online: https://www.researchgate.net/publication/33039911_Research_Review_Young_people_leaving_care (accessed on 9 May 2017). [CrossRef]

18. Wade, J.; Dixon, J. Making a home, finding a job: Investigating early housing and employment outcomes for young people leaving care. Child Fam. Soc. Work 2006, 11, 199-208. Available online: http://eprints.whiterose.ac .uk/4160/1/CFSWMar06.pdf (accessed on 2 February 2017). [CrossRef]

19. Curry, S.; Abrams, L. They Lay Down the Foundation and Then They Leave Room for Us to Build the House: A Visual Qualitative Exploration of Young Adults' Experiences of Transitional Housing. J. Soc. Soc. Work Res. 2015, 6, 145-172. [CrossRef]

20. Curry, S.R.; Abrams, L.S. Housing and Social Support for Youth Aging Out of Foster Care: State of the Research Literature and Directions for Future Inquiry. Child Adolesc. Soc. Work J. 2015, 32, 143-153. Available online: https://www.researchgate.net/publication/266853715_Housing_and_Social_Support_for_Youth_Agi ng_Out_of_Foster_Care_State_of_the_Research_Literature_and_Directions_for_Future_Inquiry (accessed on 11 June 2017). [CrossRef]

21. Dworsky, A. The economic self-sufficiency of Wisconsin's former foster youth. Child Youth Serv. Rev. 2005, 27, 1085-1118. [CrossRef]

22. Trout, A.L.; Hagaman, J.; Casey, K.; Reid, R.; Epstein, M.H. The academic status of children and youth in out-of-home care: A review of the literature. Child Youth Serv. Rev. 2008, 30, 979-994. Available online: https://nebraska.pure.elsevier.com/en/publications/the-academic-status-of-children-and-youth-in-out-of -home-care-a-r (accessed on 22 July 2017). [CrossRef]

23. Mayock, P.; Corr, M.L.; O'Sullivan, E. Young People's Homeless Pathways; Homeless Agency: Dublin, Ireland, 2008; p. 178. Available online: https://www.drugsandalcohol.ie/4239/1/homeless_agency_Young-People-s -Homeless-Pathways.pdf (accessed on 14 October 2017).

24. Lakatos, E.; Cioca, L.I.; Dan, V.; Ciomos, A.; Crisan, O.; Barsan, G. Studies and Investigation about the Attitude towards Sustainable Production Consumption and Waste Generation in Line with Circular Economy in Romania. Sustainability 2018, 10, 865. [CrossRef]

25. Bryman, A. Qualitative Research on Leadership: A Critical but Appreciative Review. Leadersh. Q. 2004, 15, 729-769. Available online: https://www.researchgate.net/publication/223792713_Qualitative_research_on_le adership_A_critical_but_appreciative_review (accessed on 14 October 2017). [CrossRef] 
26. Browne, K. The Risk of Harm to Young Children in Institutional Care; Save the Children and Stephen Austin \& Sons Ltd.: London, UK, 2009; Available online: https://www.crin.org/en/docs/The_Risk_of_Harm.pdf (accessed on 15 June 2016).

27. Bilson, A.; Cox, P. Caring about Poverty. J. Child Poverty 2007, 13, 37-55. Available online: https://www.scirp. org/(S(vtj3fa45qm1ean45vvffcz55))/reference/ReferencesPapers.aspx?ReferenceID=1568813 (accessed on 15 September 2017). [CrossRef]

28. Kligman, G. Politica Duplicității. Controlul Reproducerii în România Lui Ceaușescu. The Politics of Duplicity. The Control of Reproduction in Ceaușescu's Romania; Humanitas: Bucharest, Romania, 2000; pp. 34-67.

29. Șoitu, C.T.C. Adolescenții Instituționalizați. Implicații Psiho-Sociale Ale Mediului Rezidențial; Editura Fundației AXIS: Iași, România, 2004; pp. 28-45.

30. Rus, A.V.; Stativa, C.; Pennings, J.S.; Cross, D.R.; Ekas, N.; Purvis, K.B.; Parris, S.R. Severe punishment of children by staff in Romanian placement centers for school-aged children: Effects of child and institutional characteristics. Child Abuse Negl. 2013, 37, 1152-1162. Available online: http:/www.sasca.eu/wp-content/uploads/2018/10/Revi sta-de-Asisten\%C5\%A3\%C4\%83-Social\%C4\%83-Violence-and-Trauma-in-the-Romanian.pdf (accessed on 6 April 2017). [CrossRef] [PubMed]

31. Martin, P.Y.; Jackson, S. Educational success for children in public care: Advice from a group of high achievers. Child Fam. Soc. Work 2002, 7, 121-130. Available online: https://psycnet.apa.org/record/2002-01253-004 (accessed on 10 February 2017). [CrossRef]

32. Williams, J.G.; Jackson, S.; Maddocks, A.; Cheung, W.Y.; Love, A.; Hutchings, H. Case-control study of the health of those looked after by local authorities. Arch. Dis. Child 2001, 5, 280-285. Available online: https://www.ncbi.nlm.nih.gov/pubmed/11567933 (accessed on 22 January 2018). [CrossRef] [PubMed]

33. Cairns, K. The effects of trauma on childhood learning. In Nobody Ever Told Us School Matters: Raising the Educational Attainments of Children in Care; Jackson, S., Ed.; British Agencies for Adoption and Fostering: London, UK, 2001; pp. 191-205.

34. Goian, C. Transnational Wellbeing Analysis of the Needs of Professionals and Learners Engaged in Adult Education. Procedia Soc. Behav. Sci. 2014, 142, 380-388. [CrossRef]

35. Newman, T.; Blackburn, S. Transitions in the Lives of Children and Young People: Resilience Factors; Scottish Executive: Edinburgh, UK, 2002; pp. 91-112.

36. Zinn, A.; Palmer, A.N.; Nam, E. The predictors of perceived social support among former foster youth. Child. Abuse Negl. 2017, 72, 172-183. Available online: https://www.sciencedirect.com/science/article/abs/pii/ S0145213417302703 (accessed on 20 November 2017). [CrossRef] [PubMed]

37. Dixon, J.; Wade, J.; Byford, S.; Weatherly, H.; Lee, J. Young People Leaving Care: A Study of Costs and Outcomes: Final Report to the Department for Education \& Skills; Social Work Research and Development Unit, University of York: York, UK, 2006; Available online: https://www.york.ac.uk/inst/spru/research/pdf/leaving.pdf (accessed on 3 January 2017).

38. Munro, E.R.; Stein, M. Introduction: Comparative Exploration of Care Leavers' Transition to Adulthood. In Young People's Transitions from Care to Adulthood: International Research and Practice; Stein, M., Munro, E.R., Eds.; Jessica Kingsley: London, UK, 2008; pp. 11-20.

39. Goian, C. Ten Categories of Inconsequentialities from the Romanian Social Work Language. Soc. Work Rev. 2010, 1,79-90. Available online: https://www.ceeol.com/search/article-detail?id=64344 (accessed on 30 April 2019).

40. Williamson, J.; Greenberg, A. Families, Not. Orphanages. Research Report, Better Care Network. 2010. Available online: https://bettercarenetwork.org/library/particular-threats-to-childrens-care-and-protection/ effects-of-institutional-care/families-not-orphanages (accessed on 19 May 2017).

(C) 2019 by the authors. Licensee MDPI, Basel, Switzerland. This article is an open access article distributed under the terms and conditions of the Creative Commons Attribution (CC BY) license (http://creativecommons.org/licenses/by/4.0/). 